\title{
African Tour, 1970
}

The next FPS African tour, planned for January/February 1970, will break new ground, taking in some little-visited reserves in Uganda, notably the beautiful Kidepo Valley National Park in the north, and if possible the newly declared Awash National Park in Ethiopia. This article describes a preliminary tour made by the Hon Secretary and the Editor in February this year to prospect for the tour.

TTE Kidepo Valley National Park in northern Uganda is one of the finest and least known parks in East Africa. It will be one of the high spots of the FPS 1970 East African tour. Its setting is superb, in the spectacular, mountainous Karamoja country on the Sudan border; it has both a great variety of animals and birds, and great numbers of them.

There had been no rain for weeks on the day that we arrived in Kidepo, and looking out from the porch of our banda (all the creature comforts here) we could see animals in every direction, attracted by the river and the dam: large numbers of waterbuck grazing the grass slopes in front leading down to the water; a buffalo herd 50 or 60 strong on the other side; elephants browsing among the trees away to the right; to the left countless kongoni (Jackson's hartebeest) and Grèvy's zebra. In an hour's run in the afternoon we added eland, black rhino, oribi and 25 roan antelope among others to our tally. In the next few days there were vervet and blue monkeys among the borassus palms, Bright's gazelles, reedbuck, olive baboons and warthogs, lions and Rothschild's giraffes, and innumerable birds, including the enormous Abyssinian ground hornbills. Lesser kudu, one of the park's specialities, eluded us, though normally easy to see; the very rarely seen greater kudu inhabit the dominating Morongole mountain.

But perhaps the greatest joy of Kidepo was the quiet and remoteness which other much-visited parks have inevitably lost. On the excellent system of tracks we drove every day seeing nobody and no other vehicle. This obviously cannot last, but it is well worth savouring it while it does. The Karamajong people, too, are immensely impressive-tall, slim, proudly independent, many of the men still striding about naked.

The Budongo Forest, too, is off the beaten tourist track. Here the chief attraction is chimpanzees, which can be heard frequently in their noisy crashings and screamings about the forest. Colobus monkeys are quite common. On the edge of the forest Don Bagguley (who has a baby chimp rescued from the forest in the house) has his comfortable and well-run rest house and beautiful garden. On the Semliki plains, also little visited, a diversity of game includes large numbers of Uganda kob.

The older national parks, Queen Elizabeth and Murchison Falls, may have lost their wild remoteness, but the wildlife is still spectacular and the more conspicuous species are so tame you could photograph them with a No. 2 Brownie. The lodges are models for comfort and beautifully sited - the newest one, Chobe in Murchison Falls, has a superb position on the bank of the Nile overlooking the rapids. The 
launch trips at both parks are highlights of any visit, with vast numbers of hippos that hardly bother to move for the boat, elephants, antelopes and all the other game on the banks, innumerable birds, and, below the Falls, great crocodiles hauled out on the islets and sandbanks, with that splendid view of the Falls themselves as the climax. At Queen Elizabeth, where our tour will start, there are immense herds of topi on the Ishasha plains, where lions loll in trees waiting to be photographed, and we had splendid close-up views of giant forest hog. On the edge of the Maramagambo forest we saw chimpanzees; at the hippo pool seventeen lions waited to feast on a dead hippo at the water's edge which they could not get at because they did not want to get their feet wet. (No doubt the hyenas did not mind.) In Murchison the shores of Lake Edward offer that most magnificent sight - great numbers of plains game peacefully feeding and intermingling; and there is a good chance of seeing white rhino.

The visit to Ethiopia (probably four or five days) will be offered at the end of the tour as an optional extra, and take in the new Awash National Park and the beautiful Lake Abiata in the Rift Valley. On this great lake thousands of flamingos, greater and lesser, provide a spectacle that is always breathtaking, together with pelicans, ibises, and a great array of shore and water birds.

Awash, like Kidepo, is a small park with spectacular mountain scenery, dominated by a huge volcano, Mount Fantale, which we climbed (incredibly) in a jeep. From the edge of the huge crater we looked down into a vast area of rocks and trees where Chanler's reedbuck and klipspringer could be espied. Near the foot of the mountain is a small pool among the dom palms, the water supplied by hot springs, where we bathed in water that was almost too hot. (The next pool really was too hot.)

The park abounds in that most graceful of oryxes, the beisa oryx. One of the loveliest sights one evening was a line of these long-horned beasts silhouetted against the darkening sky as they stood motionless in profile on the high edge of a flat-topped mountain. The park's other specialities, greater and lesser kudu, are both easily seen; tiny dik-dik seemed to lurk behind every bush. Birds were numerous and exciting. One of the most incredible and beautiful sights was a group of trees so full of carmine bee-eaters (and just one carmine bee-eater is an incredibly beautiful sight) that the trees appeared to have blossomed all over with crimson flowers - all twittering. An excellent illustrated account of Ethiopia's wildlife, by John Blower, was published in ORYX, May 1968.

The details of this tour, which will be led by Sir Hugh Elliott, are now being worked out and will be sent to members; Alan Root is handling it in East Africa. If you are interested in joining and would like early information please write to Miss Giles at the FPS office.

MAISIE FITTER

\section{Shimba Hills Reserve}

The Shimba Forest in southern Kenya, which contains almost the entire Kenya population of the sable antelope, has been officially gazetted as a national reserve. The sable herd numbers about 60 . With outside help an ecological study is to be made to enable Kenya National Parks to plan the management of this new reserve. 